Ecological Research (1994) 9, 361

\title{
Corrigenda for Volume 8
}

\section{Number 1}

p. 531.40

for $\left(\mathrm{cm}^{2} \mathrm{~m}^{-2}\right)$

$\operatorname{read}\left(\mathrm{cm}^{2} / 100 \mathrm{~m}^{2}\right)$

Number 2

p. 173, Abstract, 1. 12

for reproduced vegetatively

read enhanced vegetative reproduction

p. $181,1.2$

for aggregation

read aggregated 